\title{
Sosyal Medya Uygulamalarında Yok Olan Mesaj/Veri Kavramı ve Gençlerin Kullanım Motivasyonları
}

\section{Yeşim Ceren Çapraz}

doktora öğrencisi, galatasaray üniversitesi, iletişim fakültesi medya ve iletişim çalışmaları bölümü yesimcapraz@gmail.com

Orcid: 0000-0001-5801-4163

\begin{abstract}
The Concept of Dissapearing Data on Social Media and The Usage Motivation of Youth

Social media applications, while sharing the common general features of their web-based technologies, differentiate from each other by some of their specific features. The disappearing-message/data feature was started to be used in 2011 with Snapchat and this feature has integrated into other applications (Facebook, WhatsApp, Instagram) by 2016. The purpose of this study is to reveal the goals and motivations for using the disappearing-message/ data feature and how it is differentiated from the archived messages about the content. In the study, "in-depth interview" and "focus group discussions" techniques of the qualitative method were used for obtaining the data and 57 persons were interviewed in total. As a result of the study, it was concluded that the disappearing-message/data function using motivations have been confidentiality, spontaneous photo sharing, communicating with the immediate surroundings, and being carefree among young people.
\end{abstract}

Keywords: Social Media, Disappearing-message, Disappearing Data, Instagram Story, Snapchat. 


\section{Résumé}

\section{Le concept de messages/données disparues sur les médias sociaux et la motivation d'utilisation de la jeunesse}

Les applications des médias sociaux, tout en partageant les caractéristiques communes des technologies Web 2.0, se différencient l'une de l'autre par certaines de leurs aspects spécifiques. La fonctionnalité de messages/données disparues a commencé à être utilisée en 2011 avec Snapchat et cette fonctionnalité a été intégrée en 2016 par les autres applications (Facebook, WhatsApp, Instagram). L'objectif de cette étude est de révéler les objectifs et motifs pour utiliser la fonctionnalité de message/données disparues et de comprendre comment elle se différencie des messages archivés en tant que contenu. Dans cette étude, les techniques d'entretien approfondi et de groupe de discussion ont été utilisées et au total 57 personnes de 13 à 17 ans furent interviewées. Il a été conclu que la fonction de message/données perdues des jeunes était utilisée avec des motivations de confidentialité, de partage de photos spontané, communication avec l'environnement proche et d'insouciance.

Mots-clés: Média Sociaux, Message Disparues, Donnée Disparues, Instagram, Snapchat, 


\section{Öz}

Sosyal medya uygulamaları web tabanlı teknolojilerin genel ortak özelliklerini paylaşıyor olsalar da bazı spesifik özellikleriyle birbirlerinden ayrışmaktadırlar. Kaybolan mesaj/veri özelliği de 2011 yılında Snapchat adlı sosyal medya uygulaması ile kullanılmaya başlanmış olup, küresel çapta tüm kullanııılar tarafından benimsendiğinden 2016 yılında Facebook, WhatsApp ve Instagram tarafından bu özellik uygulamalara entegre edilmiştir. Kaybolan mesaj/veri kavramı kullanıcılar tarafından üretilen ve paylaşılan verilerin belirli bir zaman sonra otomatik olarak silinmesi ve arşivlenmemesi özelliğidir ve sosyal medya uygulamalarında arşivlenebilirlik ve düzenlenebilirlik özellikleri bakımından bir kırılma yaratmıştır. Böylelikle bu özellik yeni bir iletişim biçimi oluşturarak farklı iletişim taleplerine cevap vermiştir. Bu çalışmanın amacı, kaybolan mesaj/veri özelliğinin, hangi amaç ve motivasyonlarla kullanıldığını, arşivlenen mesajlardan içerik olarak nasıl ayrıştığını ortaya çıkarmaktır. Çalışmada, verilerin elde edilmesi için niteliksel yöntemin 'derinlemesine görüşme' ve 'odak grup tartışmaları' tekniklerinden yararlanılmıştır ve toplamda 13-17 yaş aralığında 57 kişiyle görüşülmüştür. Araştırmanın sonucunda gençlerin kaybolan mesaj/veri özelliğinin gizlilik, anlık (spontane) fotoğraf paylaşımı, yakın çevre ile iletişim ve kaygısızlık motivasyonlarıla kullanıldığı sonucuna varılmıştır.

Anahtar Kelimeler: Sosyal Medya, Kaybolan Mesaj, Kaybolan Data, Instagram Hikaye, Snapchat. 


\section{Giriş}

Sosyal medya, Web 2.0'ın ideolojik ve teknolojik temelleri üzerine kurulmuş olan internet tabanlı bir grup uygulamadır ve kullanıc tarafından yaratılan içeriğin oluşturulmasına izin veren bir araçtır (Kaplan ve Haenlein, 2010). Web 2.0 teknolojisinin bir uzantısı olan sosyal medya kavramı "kullanıcı-tabanlı" içerik üretim modeline dayanmaktadır ve kullanıcılar "tüketen-üretici" olarak adlandırılmaktadır. İngilizce'de "prosumer" olarak adlandırılan bu kavram üretici anlamındaki "producer" ve tüketici anlamındaki "consumer" kelimelerin birleştirilmesinden oluşturulmuştur (Quan-Haase ve Young, 2010). Sosyal ağ siteleri bireylere kendilerini ifade etme, sosyal ağlarını eklemleyerek birleştirme, diğerleri ile bağlantılar kurup bu bağlantıları sürdürme olanağı veren çevrimiçi alanlardır (Ellison, Steinfield ve Lampe 2006, s.3). Her sosyal medyanın kendine özgü avantajları ve kullanım biçimleri mevcut olsa da, bir içeriğin yaratılması ve bu içeriğin paylaşımasıyla kullanıcılar arasında oluşan bilgi (enformasyon) değiş tokuşu sosyal medya platformlarının ortak özelliğidir (Taprial ve Priya, 2012).

Internetin ilk zamanlarında, web 2.0 teknolojisi öncesinde, internetin sağladığı olanaklar sınırlı olduğu gibi, aynı zamanda internete erişim de oldukça sınırlıydı. TUiK raporuna göre, 2007 yılında internete erişim olan hane oranı \%20 iken, 2015 yılında bu rakam \% 70'lere yaklaşmıştır ve Türkiye nüfusunun \%60'ını oluşturan 48 milyon kişi ise internet ve sosyal medya kullanıcısıdır. Dünya genelinde bakıldığı zaman, Digital in 2017 Global Overview (Ayvaz, 2017) raporuna göre, nüfusunun yarısından fazlası en az 1 tane akıllı telefon sahibidir. 3.77 milyar internet kullanıcısı bulunurken, 2.80 milyar insan ise aktif olarak sosyal medya kullanmaktadır. We are social ve Hootsuit tarafından her yıl hazırlanan sosyal medya kullanıcı verileri, aktif sosyal medya kullanıcı sayısının geçtiğimize yıla oranla 3 milyonluk bir artışla 51 milyon kullanıcıya ulaştığını göstermektedir. ${ }^{1}$ Sadece Facebook uygulamasının 2,23 milyar kullanıcı sayısına ulaşması ${ }^{2}$, sosyal medya uygulamalarının küresel çapta fenomen haline geldiğini işaret etmektedir. ABD'de yapılan bir araştırmaya göre Youtube'un ABD'deki herhangi bir kablo ağından 1834 yaş arası ve 18-49 yaşları arasında daha fazla eriştiği tespit edilmiştir (BağCı, 2017). Bu istatistik aslında enformasyonun internet aracılığıyla kitlelere ulaşma gücünü ve potansiyelini yansıtması açısından değerlidir. İnternetin etkileşim, çoklu ortam, düzenlenebilirlik, saklanma gibi özellikleri geleneksel kitle iletişim araçlarının sağladığı tüm içeriklerin internet ortamından da takip edilmesine olanak sağlaması sosyal medya kullanımının artışında önemli bir faktördür.

Sosyal medya kullanıcı sayısı hızla artarken, sosyal medya platformları da her geçen gün çeşitlenmektedir. Halihazırda kapsam ve işlevsellik açısından farklılık gösteren birçok sosyal medya sitesi mevcuttur. Sosyal medya uygulama-

\footnotetext{
1 https://dijilopedi.com/2018-turkiye-internet-kullanim-ve-sosyal-medya-istatistikleri/ adresindeki bilgilere dayanmaktadır. (Erişim tarihi: 11.11.2018)

2 https://www.sabah.com.tr/teknoloji/2018/07/25/facebookun-aylik-kullanici-sayisi-223-milyara-ulasti adresindeki bilgilere dayanmaktadır. (Erişim tarihi: 15.11.2018).
} 
larının genellikle ortak özellikleri paylaştıkları fakat bazı spesifik özellikleriyle de birbirlerinden ayrıldıkları görülmektedir (Vaterlaus vd., 2016). İlk olarak Snapchat ile başlayan ve daha sonrasında ise Facebook, WhatsApp ve Instagram'ın da kendi uygulamalarına entegre ettiği "kaybolan mesaj/veri" özelliği de sosyal medya uygulamalarının spesifik bir özelliği olarak ortaya çıkmıştır. Bu özellik sosyal medyanın arşivlenebilirlik ve düzenlenebilirlik kavramları açısından bir kırılma yaratmış olup, kaybolan mesaj/veri paylaşılan içeriklerin yapısını değiştirerek iletişim dinamiklerini değiştirmiştir. Sosyal medya uygulamalarına ait bu özelliğin, özellikle gençler arasında hangi motivasyonlarla kullanıldığını araştırmak, yeni iletişim teknolojilerinin dinamiklerini anlamak için önemlidir.

Bu çalışmada, kullanımlar ve doyumlar kuramı esas alınarak, kaybolan mesaj/veri özelliğine sahip olan Facebook, WhatsApp, Snapchat ve Instagram uygulamalarının kullanım nedenleri ile motivasyonlarını ve bu kullanımlardan elde edilen doyumları bir saha araştırmasıyla (13-17 yaş aralığında 57 kişi ) incelemiştir. Bu çalışmanın temel amacı, genç bireylerin kaybolan mesaj/veri özelliğini hangi doyum ve motivasyonlarla kullandıklarını ortaya koymaktadır.

\section{Kavramsal Çerçeve: Kullanımlar ve Doyumlar Yaklaşımı}

Bu çalışma, genç bireylerin "kaybolan mesaj/veri" kavramını nasıl kullandıklarını ve bu kullanımlardan elde ettikleri doyumları sorgulamakta, genç bireylerin gündelik yaşamlarında, evde, diğer toplumsal veya bireysel ortamlarda bu özelliğe sahip sosyal medya mecraları ile nasıl bir ilişki içerisinde olduklarını ortaya çıkarmayı amaçlamaktadır. Bu çalışma, kuramsal olarak, "kullanımlar ve doyumlar" (uses and gratifications) yaklaşımından yola çıkılarak gerçekleştirilmiştir. Bu model, ayrıntılı biçimde ekonomi politik kuramlarından beslenmese de, en azından makro ölçekte, sosyo-ekonomik koşullar ve bağlamı da (medya izleme pratikleri ve kullanımının, hem medyanın, hem de izleyicilerin toplumsal ve ekonomik koşulları ile bağıntılı olması anlamında) dikkate almıştır.

1990'ların sonlarına kadar, kullanımlar ve doyumlar yaklaşımıyla, izleyici odaklı çalışmalar gazete, radyo ve televizyon üzerine odaklanmıştır (Berelson, 1949; Rubin, 1983; Schramm, Lyle ve Parker, 1961; Stanton ve Lazarsfeld, 1944). Bu kitle iletişim araçlarında, izleyicinin seçtiği içeriklerin ve araçların oldukça sınırIı olmasından ötürü araştırma sahaları da sınırlı kalmıştır. Fakat internetin gelişmesiyle birlikte, izleyicilerin seçenekleri neredeyse sınırsızlaşmıştır ve internetin içeriğinin zenginliği gereği araştırma konuları da zenginleşme imkânına sahip olmuştur. Kullanımlar doyumlar yaklaşımı da yeni iletişim teknolojilerinin rolünün incelenmesinde önemli bir teorik perspektif sunmuş, böylelikle kullanımlar doyumlar araştırmaları yeni medya ile birlikte yeniden canlanmış ve önem kazanmıştır (Papacharissi, 2008, Rubin, 2002, Ruggiero, 2009, Ayhan ve Çavuş, 2014).

Her ne kadar Webster ve Shu-Fang, (2002) çalışmalarında, internet kullanıcılarının da geleneksel medya izleyicileri gibi "izleyici" olarak düşünülebileceğinin 
altını çizse de, internet odaklı araştırmalarda, kullanımlar ve doyumlar yaklaşımını güçlendiren en önemli faktör internetin kişisel bir mecra olmasıdır. Kullanıcılar internette birçok seçenek arasından kendi seçimlerini belirlemektedirler. 2000 sonrası internet hakkındaki çalışmalar genel olarak internet kullanımı, internet bağımlılıkları, online oyunlar ya da sosyal medya gibi farklı alanlara odaklanmıştır ve çalışmaların genel olarak genç izleyicilerin kullanım motivasyonlarını araştırdığı dikkat çekmektedir (Park, 2004).

Kullanıcı sayısının çokluğuyla en büyük sosyal medya mecralarından biri olan Facebook uygulamasının kullanımlar ve doyumlar yaklaşımıyla birçok araştırmaya konu olduğu görülmektedir. Bumgarner (2007) Facebook kullanım motivasyonlarını araştırdığı çalışmasında, üniversite öğrencilerinin Facebook'u en çok sosyal aktivite motivasyonu ile kullandığı sonucuna ulaşırken, Park ve arkadaşları (2009) yaptıkları çalışmada üniversite öğrencilerinin sosyalleşme, eğlence, statü arayışı ve bilgi arayışı motivasyonları ile Facebook'u kullandıklarını tespit etmişlerdir. Türkiye çapında yapılan araştırmalara bakıldığında ise, Kösoğlu (2012) Facebook uygulaması için fotoğraf/video, kullanım kolaylığı, topluluk gündemini yakalama, magazin konuları, kullanım tercihleri ve sosyal bağlantılar olarak 6 farklı kullanım ve doyum saptarken, Yıldııı ve arkadaşları (2018) çalışmalarında ise Facebook kullanım motivasyonlarının sosyal çevre ile (aile, arkadaş vs.) iletişim halinde olmak, haber takibi, etkinlik takibi, grup ve sayfa paylaşımlarını takip etme olduğunu ortaya koymuştur.

Dünya genelinde kullanıcı sayısı 1 milyarı geçen Instagram uygulamasına ${ }^{3}$ bakıldığı zaman, Yayla (2018) yaptığı çalışmasında kullanımlar ve doyumlar yaklaşımıyla 2016 yılında 151 üniversite öğrencisi ile gerçekleştirdiği anket çalışması sonucunda, Instagram'ın eğlence, sosyal kaçış, kişisel gelişim, arkadaşlık, ekonomi, takip etme ve kişisel sunum motivasyonları ile kullanıldığı ortaya koymuştur. ${ }^{4}$ Bir diğer kaybolan mesaj/veri özelliğine sahip olan WhatsApp uygulamasının ise, Göncü'nün (2018) çalışmasına referansla sosyalleşme (toplumsal etkileşim), ücretsiz olması, pratiklik, multimedya (yöndeşme), profesyonel ihtiyaçlar (mesleki) ve eğlence motivasyonlarıyla kullanıldığı görülmektedir. WhatsApp'ın kaybolan mesaj/veri özelliğinin de eğlence motivasyonu ile kullanıldığı bu çalışma içerisinde tespit edilmiştir.

Amerika'da 18-23 yaş arası kişilerle yapılan çalışmada (Vaterlaus et al., 2016), Snapchat uygulamasının daha kişisel paylaşımların yapıldığı bir mecra olduğu ortaya çıkmıştır. Snapchat'in spesifik özellikleri sayesinde kullanıcıların yakın çevreleriyle kişiler arası iletişimlerini pekiştirdikleri, eğlenceli fotoğraflar ve anlık (spontane) mesajlarla kullanıcıların hislerini daha çok belirtebildikleri çalışmanın bulguları arasındadır. Bu çalışma aynı zamanda kullanıcıların ebeveynleri ile olan jenerasvon farkının Snapchat uygulamasında net olarak görülmesini sağlamış 3 http://www.tech-worm.com/instagram-kullanici-sayisi-1-milyari-gecti/ adresindeki bilgilere dayanmaktadır. (Erişim tarihi: 15.08.2018)

4 Araştırmanın yapıldığı 2016 yılında Instagram uygulamasında kaybolan mesaj/veri özelliği bulunmamaktadır. 
böylelikle Snapchat'in gençlere kendi iletişim kültürlerini oluşturma imkanı sunduğu kanısına ulaşılmıştır. Türkiye'de ise Kara (2016) Snapchat ile ilgili yaptığı araştırmasında, gençlerin uygulamanın kullanımından eğlenme, kullanım rahatlığı, kişisel rahatlama, bilgi paylaşma, sosyal etkileşim, beğenilme/takdir edilme ve gözetleme doyumlarını elde ettiği sonuçlarına ulaşmıştır.

Yukarıda bahsedilen araştırmalar ışığında, bu çalışmanın amacını, kullanımlar ve doyumlar yaklaşımından yola çıkarak, kaybolan mesaj/veri özelliğine sahip Facebook, Instagram, WhatsApp ve Snapchat uygulamalarının gençlerin hangi gereksinimlerini doyurmak için nasıl kullanıldığını ortaya koymayı amaçlamaktadır.

\section{Kaybolan Mesaj/Veri Kavramı}

Boyd ve Ellison (2008, s. 211) sosyal ağ sitelerini, "bireylerin, sınırlandııımış bir sistem içinde kamuya tamamen açık ya da yarı açık profiller inşa etmesine, bir şeyler paylaştıkları kullanıcılardan oluşan bir liste oluşturarak bunu ilan etmelerine ve sistem içerisinde kendileri ya da başkaları tarafından oluşturulmuş bağlantı listelerini inceleyip karşılaştırmalarına olanak sağlayan web temelli hizmet siteleri" olarak tanımlamaktadırlar. Sosyal medya uygulamalarını uygulamaların aldığı sık güncellemelerden dolayı sınıflandıııması zor olsa da, Kaplan ve Haenlein, (2010) sosyal medyanın fırsatlarını ve engellerini tartıştıkları çalışmalarında 6 farklı kategori olarak ele almışlardır; işbirlikçi projeler (örn. Vikipedi), bloglar ve mikrobloglar (örn. Twitter), içerik toplulukları (örn: twitter), sosyal paylaşım ağları (örn. Facebook), sanal oyun dünyaları (örn. Worlds of warcraft), sanal sosyal oyun dünyaları (örn. Second life). Sosyal medya en çok kullanılan Facebook ve Twitter uygulamalarının yanı sıra bloglar, sanal oyun dünyaları gibi platformların da genel adıdır.

Taprial ve Priya (2012) sosyal medyayı güçlü kılan 5 önemli faktörün olduğunu vurgulamaktadır; erişebilirlik, hız, interaktiflik, kalıcılık ve ulaşılabilirlik. Treem ve Leonardi (2013) ise sosyal medyayı dört önemli kavram üzerinden tanımlamaktadır; görünürlük, saklanma/arşivlenme, düzenlenebilirlik ve iştirak/birliktelik5 . Her iki tanım da, paylaşılan içeriklerin uygulamalar içerisinde kalııı ve saklanıyor olmasına vurgu yapmaktadır. Kaybolan mesaj/veri özelliği sosyal medya uygulamalarına dahil olana kadar, sosyal medyada yaratılan ve paylaşılan içerikler kullanıcılar silmediği sürece saklanmış ve arşivlenmiştir. Hatta sosyal medyanın dijital olarak bir arşiv ve anı mecrası oluşturduğu birçok çalışmaya konu olmuştur (Garde-Hansen vd., 2009, Van Dijck, 2007, Özkul ve Humphreys, 2015). Sosyal medya uygulamalarında elbette arşiv ve anı biriktirme özellikleri hala mevcuttur. Fakat artık sadece arşivlenen veriler değil, ileriki bölümlerde de ele alınacağı gibi ephemeral (anlık) teknolojiler olarak adlandırılan kaybolan veri özellikleri de uygulamaların özellikleri arasında yer almaktadır.

5 Makalenin orijinalinde bu kavramlar, affordances of visibility, editability, persistance ve association olarak geçmektedir. 
Kaybolan mesaj/veri de bir sosyal medya uygulaması özelliğidir ve gönderilen içeriklerin, arşivlenmeyerek belirli bir zaman sonra kaybolması (silinmesi) olarak tanımlanabilir. Kaybolan mesaj özelliği Facebook, WhatsApp, Instagram ve Snapchat uygulamalarında mevcuttur. Kaybolan mesaj/veri kullanımının iki farklı kullanım türü mevcuttur;

Direkt mesaj özelliği: Bu özellik, sadece Snapchat ve Instagram uygulamalarında bulunmaktadır. Oluşturulan içeriğin Snapchat ve Instagram'dan direkt olarak seçilen belirli kişilere gönderilmesi ve gönderen kişinin belirlediği süre (10 saniye ve altı) kadar görüldükten sonra anında kaybolma özelliğidir.

Hikâye Özelliği: Bu özellik Facebook, Snapchat, Instagram ve WhatsApp uygulamalarında bulunmaktadır. Oluşturulan içeriğin uygulamada kullanıcıların tüm arkadaş listesi ile doğrudan paylaşılabildiği ve içeriklerin 24 saat sonrasında uygulama tarafından otomatik olarak silinme özelliğidir.

Sosyal medya platformlarının bu özelliği, ephemeral iletişimin bir biçimi olarak tanımlasa da, Tablo 1'de de görüleceği gibi kaybolan mesaj/veri özelliği sadece ephemeral olarak değil, literatürde farklı kavramlarla tanımlanmıştır.

"Kaybolan mesaj/veri" özelliği, Treem ve Leonardi'nin (2013) sosyal medya için yaptıkları görünürlük, saklanma/arşivlenme, düzenlenebilirlik ve iştirak/birliktelik tanımlarında bir kırılmaya yol açmıştır. Kaybolan mesaj/veri kavramı, Türkçe'de "kaybolan" olarak kullanıldığı için bu çalışmada bu şekilde kullanılmıştır. Fakat belirtilmelidir ki, "kaybolan" kelimesi hem bir negatif tanım içermektedir hem de bu özelliğin içeriğini iyi yansıtmamaktadır. Kaybolan mesaj özelliği, esasında üretilen ve sonrasında paylaşılan bir içeriğin uygulamanın özelliğinde olan bir şekilde kendi kendine bir zaman sonra silinmesi anlamındadır. Bu nedenle "arşivlenmeyen", "kendi kendine silinen mesaj uygulamaları" gibi tanımlar bu uygulamaların özelliklerini daha iyi yansıtabilir.

Yapılan diğer çalışmalarda ise, kaybolan mesaj kavramı "kaybolan data", "geçici medya" (temporary medya), "zaman sınırlı anlık mesaj" (time-limited instant message), "anlık mesaj" (ephemeral message) kavramlarıyla ele alınmaktadır.

Tablo 1. Kaybolan Mesaj/Veri Kavramının Literatürde Farkıı Kullanımları

\begin{tabular}{|l|l|}
\hline Disappearing Data & (Charteris ve Gregory, 2014) \\
\hline Temporary Media & (Anderson, 2015) \\
\hline Time-Limited Instant Message & (Piwek \& Joinson, 2016) \\
\hline Ephemeral Message & (Bayer et al., 2015) \\
\hline Kaybolan Mesaj & Türkçe'de yaygın kullanım \\
\hline
\end{tabular}


Kaybolan mesaj/veri özelliği için kullanılan kavramlardan biri olan "ephemeral" iletişim Türkçe'de geçici ve kısa ömürlü olarak tanımlanabilirken, her teknoloji dolaysız iletişimin de ephemeral (kısa ömürlü) olduğunu belirtmek önemlidir (Bayer vd., 2015, Charteris ve Gregory, 2014). Bu bağlamda, Snapchat, WickIr, iDelete ve Instagram gibi bahsettiğimiz uygulamalar ilk kez ephemeral (anlık) iletişim sağlayan uygulamalar değildir. Video arama özellikleri de (skype başta olmak üzere), ki bu video aracılığıyla görüşme imkânı Facebook, Whatsapp ve hatta Gmail'de bile mevcuttur, tüm video ve sesli görüşme olanakları da teknoloji dolaylı ephemeral (anlık) iletişim olarak adlandırılabilir.

Anlık iletişime örnek olarak sayılabilecek canlı yayın uygulamaları da Instagram, Facebook, Periscope gibi sosyal medya uygulamaları tarafından kullanılmaktadır. Canlı yayın uygulaması, mobil telefonların teknik şartları sağlaması halinde cep telefonunun kamerası ile canlı yayın yapılabilen bir özelliktir. 2014 yılında ilk olarak Periscope kullanmaya başlamıştır, popüler olmasından sonra Facebook bu özelliği kendine entegre etmiştir ve son olarak Instagram 2016 yılının Aralık ayında bu özelliği getirmiştir (Yılmaz, 2017). Instagram eklediği yeni özelliği ile canlı yayın içinde aynı anda takipçilerle mesajlaşmaya olanak sağlarken, bu canlı yayınları kaydetmeye ve 24 saat boyunca da "Instagram hikâyeler" bölümünde izlemeye olanak sağlamıştır.

Kaybolan mesaj/veri özelliği hakkında genel kavramları toparlarsak, anlık iletişimi simgeler, içerikleri sınırlı bir zaman diliminde görünür kılar, geçici bir sosyal medya özelliği yaratır. Tüm bu vurgular, içeriklerin arşivlenmeyerek belirli bir zaman sonrasında kaybolmasından ileri gelmektedir. Kaybolan mesaj/veri özelliğini anlatmak için kullanılan her farklı terim aslında bu kavramın bir özelliğine vurgu yapmaktadır. Geçici (temporary) sosyal medya kavramı bu gönderilen/paylaşılan içeriklerin arşivlenmeyerek kaybolmasına işaret etmektedir. "Time-limited instant message" kavramı ise içeriklerin belirli bir süre zarfında görülüyor olmasına ve o belirli süre sonunda ise siliniyor olmasına vurgu yapmaktadır.

Piwek ve Joinson (2016) çalışmalarında Snapchat'i anlık mesaj iletim ${ }^{6}$ servislerinin yeni bir kategorisi olarak yorumlamaktadırlar. Buna göre Snapchat'ı diğer IM (instant messaging) servislerinden ayıran özelik, kullanıcıların paylaştığı içeriğin yalnızca belirli bir süre görülebiliyor olmasıdır. Kavram olarak "IM", anlık mesajlaşma anlamına gelir, coğrafi olarak farklı yerlerde bulunan bireylere "gerçek zamanlı" etkileşime girme fırsatı sağlayan, senkronize yakın yazılı bir araçtır (Ramirez ve Broneck, 2009). Facebook, Twitter, Linkedln, Whatsapp gibi birçok sosyal medya anlık yani eş zamanlı mesajlaşma imkânını sağlamaktadır.

Utz ve arkadaşları (2015) çalışmalarında , Treem ve Leonardi'nin ${ }^{7}$ kavramlarından yola çıkarak, Snapchat ve Facebook karşılaştırması yapmış ve uygulamaIarın 2 önemli kavramda ayrıştıklarını vurgulamıştır; Snapchat ve Facebook görü-

6 Orijinal dilinde 'instant message' olarak kullanılmaktadır.

7 Kavramların orijinalleri visibility, editability, persistance and association olarak geçmektedir. 
nürlülük ve kalııılık kavramları üzerinden ayrışmaktadır. ${ }^{8}$ Snapchat ve Facebook özellik bakımından ayrıştığı gibi kullanıcıların kullanım motivasyonları açısından da farklılık gösterdiği yapılan çalışmalarda görülmektedir. Piwek ve Joinson, (2016) araştırmasında Snapchat'in Facebook gibi sosyal ağlara oranla, çok daha yakın bir çevre ile etkileşimde olduğunu ortaya koymuştur. Network ağlarının oluşturulduğu (Facebook ya da Linkedln gibi) bir sosyal uygulamadan ziyade, daha sıklıkla yakın arkadaşlarla ve partnerle ile iletişim kurulma amacıyla kullanıldığı gözlemlenmiştir. Snapchat kendini sansür etme ihtiyacını azalttığından, daha samimi, kişisel paylaşım biçimleriyle bağlantılı olarak kullanılmaktadır (Utz vd., 2015). ${ }^{9}$

Kaybolan mesaj/veri özelliğiyle sosyal medya mecralarında kaygısızlık olarak nitelendirilen bir kavramı da ön plana çıkartmıştır. Gerek herhangi bir beğeni ve yorumun kullanıcılar tarafından yapılamaması, gerekse uygulamanın kolaylığından dolayı yapılan araştırmada kullanıcıların kaybolan mesaj gönderirken olumlu anlamda bir kaygısızlığın hâkim olduğu tespit edilmiştir (Bayer et al., 2015). Sashittali ve arkadaşlarının (2016) yaptıkları araştırmada, Snapchat kullanan gençlerin kendilerini bu platformda yargılanmaktan uzak hissettiklerini ortaya koymuştur. Aynı çalışmada, gençler, diğer platformlarda herhangi bir içerik (fotoğraf ya da yazı) paylaşırken, bunun üzerine çok fazla düşündüklerini belirtmişlerdir. Boyd, Snapchat'i gençlerin onları paylaşımlarından dolayı yargılayabilecek herhangi bir ebeveynin, yetişkinin ya da okul yönetiminin gözetimine takılmadan özgürce eylemde bulundukları bir mecra olarak tanımlamaktadır (aktaran Sashittal, vd., 2016). Piwek \& Joinson, (2016) çalışmasında da, Snapchat'in gençlere daha özel paylaşım yapmalarına imkân tanımasından dolayı bu uygulamayı tercih ettiklerini vurgulamaktadır. Utz ve arkadaşlarının (2015) ise araştırmalarında yaptıkları anketlerde kullanıcıların kaybolan mesaj aracılığıyla en çok hangi içerikleri paylaştıklarını araştırmışlardır. Buna göre, Snapchat'te kullanıcılar sırasıyla en çok komik buldukları şeyleri, anlık hareketlerini gösteren özçekimlerini, etkinliklerini, yemeklerini ve son olarak da hayvanlar ile ilgili içerikleri paylaştıklarını vurgulamışlardır.

Snapchat'in ardından Facebook, WhatsApp ve Instagram kaybolan mesaj/ veri özelliğini uygulamalarına entegre etmiştir. Facebook 2004 yılında sosyal paylaşım ağı olarak, Instagram ise 2010 yılında dijital fotoğraf yükleme uygulaması olarak kurulmuştur. Instagram'da gruplar halinde, bireysel olarak mesajlaşma imkânları olsa da Instagram uygulamasında genel olarak kullanıcılar fotoğraf ve video yüklemesi yapmaktadır. Instagram'da, Facebook ya da Snapchat'ten farklı olarak arkadaş listesi yerine, Twitter'a benzer bir şekilde 'takipçi' sistemi bulunmaktadır. Son verilere göre ${ }^{10}$, Instagram son iki yılda kullanıcı sayısını iki katına çıkararak, 500 milyon kullanıcıya ulaşmıştır ve kullanıcılar uygulama üzerinden her

8 Bu araştırma, Facebook uygulaması kaybolan mesaj özelliğini içermediği 2015 tarihinde yapılmıştır.

9 Snapchat özelinde yapılan bu çıkarım, gönderildikten ve alıcı tarafından görüldükten sonra kaybolan mesaj özelliklerini içeren (örn. Instagram direkt mesaj uygulaması) tüm sosyal medya mecraları için genellenebilir.

10 http://blog.euromsg.com/sosyal-medya-hakkinda-63-istatistik/ adresindeki verilere dayanmaktadır. (Erişim tarihi: 17.05.2017) 
gün 80 milyon tane fotoğraf paylaşmaktadır. Dünya'da sosyal medya kullanıcıların \%47 si Facebook uygulamasını kullanırken, Instagram'da bu oran \%20 oranındadır. Instagram'ın kullanıcı profiline bakıldığında \%90'ını 35 yaşından küçük kişilerin oluşturduğu görülmektedir. WhatsApp uygulamasının kullanıcı sayısı da 1,5 milyara ulaşmıştır. ${ }^{11}$

Özellikle Amerika'da hızla yaygınlaşan, kurulduğu 2011 yılındaki beri büyümeye devam eden günlük 100 milyon kullanıcı sayısına ulaşan Snapchat uygulamasını Facebook birkaç kez satın alma girişiminde bulunduktan sonra, ${ }^{12}$ bünyesinde bulunan Instagram ve WhatsApp, uygulamalarına 2016 yıllında kaybolan mesaj/veri özelliğini eklemiştir. Snapchat, 2014 yılından itibaren önemli bir gelişme göstermiş olsa da, kaybolan mesaj/veri özelliği Facebook, Instagram ve WhatsApp'a entegre edildikten sonra Snapchat kullanım oranında düşüş yaşanmıştır. 2017 yılının ikinci çeyreğinin ilk iki ayına ait istatistiklere göre, Snapchat uygulamalarının toplam indirme rakamları bir önceki yıla oranla yüzde 22 oranında düşüş göstermiştir. ${ }^{13}$ Instagram'daki hikâye uygulamalarının Snapchat'ten sonra bu kadar benimsenmesi, Instagram'ın genç kullanıcı profili ile açıklanabilir. Facebook ve WhatsApp uygulamalarında ise bu yeni özellik o kadar ilgiyle karşılanmamıştır.

\section{Çalışmanın Amacı ve Yöntemi}

Temel amacı gençlerin kaybolan mesaj/veri özelliğini hangi motivasyonlarla kullandıklarını ortaya koymak olan araştırmanın yöntemi niteliksel olarak belirlenmiştir. Nitel araştırmalar "ne kadar" gibi nicel soruların cevaplarının yerine "neden" ve "nası" gibi niteliksel soruların cevaplarını arayarak çalışmaya derinlemesine bilgi sağlamaktadır. "Nitel araştırmalar geleneksel araştırma yöntemleriyle ifade edilmesi zor olan sorulara cevap bulmak için gereklidir" (Büyüköztürk vd., 2008).

Araştırmada veri toplama tekniği olarak "derinlemesine görüşme" ve "odak grup görüşmelerinden" yararlanılmıştır. Görüşme yoluyla, deneyimler, tutumlar, düşünceler, niyetler, yorumlar ve zihinsel algılar ve tepkiler gibi gözlenemeyeni anlamaya çalışılmaktadır. (Yıldırım ve Şimşek, 2008). Nitel veri toplama türlerinin temel veri toplama tekniklerinden biri olan derinlemesine görüşme "araştırma konusu ile ilgili kişilerle belirli bir amaç doğrultusunda konuşma yapılmasıdır" (Özdemir, 2010). Derinlemesine görüşmelere ek olarak, 2 odak grup görüşmesi ile çalışma zenginleştirilmiştir. Odak grup görüşmesi "॥lımlı ve tehditkar olmayan bir ortamda önceden belirlenmiş bir konu hakkında algıları elde etmek amacıyla dikkatle planlanmış bir tartışmalar serisi" olarak tanımlanabilir (Yıldırım ve Şimşek, 2008). Bireysel görüşmelerden farklı olarak, odak grup görüşmelerinde bireyler

11 https://webrazzi.com/2018/02/01/whatsappin-aylik-aktif-kullanici-sayisi-1-5-milyara-ulasti/ adresindeki verilere dayanmaktadır. (Erişim tarihi: 14.11.2018).

12 http://www.ntv.com.tr/galeri/teknoloji/facebooksnapchattensonra-o_uygulamayi-da-satin-alamadi,q5X2-MrSOka5d-AAbsFnEQ/c_4Bw1eMGUqeKtpsjygbMO.

13 http://www.milliyet.com.tr/snapchat-in-indirme-rakamlari-gun-sosyalmedya-haber-2464990/ adresindeki bilgilere dayanmaktadır. (Erişim tarihi: 24.04.2017). 
etkileşim halindedir böylelikle grup içerisinde oluşan bilgi akışı ve tartışmalar sayesinde çalışma zenginleştirilmiştir.

Araştırmanın örneklemini oluşturan görüşmecilere 40 adet açık uçlu soru yöneltilmiştir. Yöneltilen sorular dört kategoride hazırlanmıştır: 1) Demografik sorular, 2) Sosyal medya kullanım alışkanlıkları (Snapchat, Instagram, Facebook ve WhatsApp özelinde), 3) Kaybolan mesaj/veri kullanım alışkanlıkları, 4) Kaybolan mesaj/veri kullanım nedenleri.

\section{Araştırmanın Örneklemi ve Sınırlılıkları}

Niteliksel yöntemle gerçekleştirilen çalışmalarda, geleneksel bilim anlayışının "indirgeme" ilkesinden yararlanılarak, çalışma evrenini temsil etme gücüne sahip sınırlı sayıda birey çalışmaya dahil edilmesi uygun görülmektedir (Yıldırım ve Şimşek, 2008). Kaybolan mesaj/veri çalışmalarında yer alan istatistiklerde, Snapchat uygulamasının özellikle ergenlerin (teenage) grubu tarafından kullanıldığı görülmektedir. ${ }^{14}$ Fakat Dünya Sağlık Örgütü ${ }^{15}$, ergenliğin ${ }^{16}$ tanımını 10-19 yaş aralığında çok geniş bir çerçevede çizmektedir. Bu nedenle çalışma doğrultusunda daha sınırlayıcı olması açısından, örneklem grubu 13-17 yaş grubundan seçilmiştir.

Niteliksel temsiliyet gözetilerek görüşülen gençlerin seçiminde, klasik ve stratejik değişkenler kullanılmıştır. Bunlar sırasıyla, cinsiyet, yaş dilimi, ailenin sosyo-ekonomik konumu, devam edilen okulun (özel/devlet liseleri, ortaokul, güzel sanatlar lisesi, sağlık meslek liseleri, kız/erkek imam hatip liselerin) niteliğidir. Stratejik değişken olarak, görüşmecilerin "Snapchat, Facebook, WhatsApp ve Instagram uygulamalarını aktif olarak kullanıyor olmak" ölçütü dikkate alınmıştır.

Görüşülen gençlere, bir tanıdığını önermesi olarak özetleyebileceğimiz "kartopu" (snowball) tekniğinden yararlanılarak bireysel ağlar yardımıyla ulaşımıştır. Araştırmada gerçekleştirilen odak grup görüşmeleri ile derinlemesine görüşmeler Nisan 2017 ve Haziran 2017 tarihleri arasında gerçekleştirilmiştir. Araştırmada 30 tane derinlemesine görüşme ile birlikte biri 17 kişilik diğeri ise 7 kişilik olmak üzere toplamda 2 odak grup görüşmesi gerçekleştirilmiştir. Yapılan görüşmelerin süresi birbiriyle farklı olmakla birlikte ortalama bir görüşme yarım saat civarında sürmüştür.

Araştırma örneklemi demografik olarak heterojen seçilmeye çalışılsa da, maddi kısıtlılıklardan dolayı (13-17 yaş aralığında belirlenen örnekleme dahil gö-

14 İlk olarak Snapchat uygulaması kaybolan mesaj/veri özelliğine sahip olduğu için, örneklem oluşturulurken Snapchat kullanım istatistikleri baz alınmıştır. Türkiye'de ise Snapchat kullanım oranlarının yaşa göre istatistiksel hakkında spesifik bir istatistiğe rastlanılmadığından yurtdışındaki istatistiklerin değerlendirildiği belirtilmelidir.

15 http://pdrgunlugu.net/dunya-saglik-orgutune-gore-ergenlik/ adresindeki bilgilere dayanmaktadır. Erişim tarihi: 10.06.2017

16 Bu çalışmada görüşmecilere ergenler olarak değil, gençler olarak hitap edilmektedir. 
rüşmecilerin reşit olmamasından ötürü velilerinden izin alma zorunluluğundan doğan katılım sorunları, gerçekleştirilen odak grup görüşsmelerinde öngörülenden daha az ya da daha çok kişinin katılım göstermesi, katılımcılara ancak bireysel ağlarla ulaşabilme, araştırmanın tek bir bölgede yapılabilmesi vb.) örneklemin sosyo-ekonomik durum, eğitim düzeyi (devam ettikleri lise türü), cinsiyet dağılımı bakımından çalışmada bazı sınırlııklar doğurmuştur.

Toplamda 16 erkek ve 41 kız çeşitli lise/ortaokullarda okuyan gençlerle görüşülmüştür ${ }^{17}$.

Tablo 2. Görüşülen Kişilerin Sosyo-Ekonomik Yapılarının Cinsiyete Göre Dağılımları

\begin{tabular}{|l|l|l|l|}
\hline Ses ${ }^{\mathbf{1 8}}$ & Kişi Sayısı & Kız & Erkek \\
\hline$A B$ & 9 & 6 & 3 \\
\hline$C 1 / C 2$ & 29 & 21 & 8 \\
\hline$D E$ & 19 & 14 & 5 \\
\hline TOPLAM & 57 & 41 & 16 \\
\hline
\end{tabular}

Tablo 3. Görüşelen Kişilerin Liselere Göre Dağııımı

\begin{tabular}{|l|l|}
\hline Lise Türleri & Kişi Sayısı \\
\hline Özel Lise & 6 \\
\hline Anadolu Lisesi & 10 \\
\hline Güzel Sanatlar Lisesi & 5 \\
\hline Sağlık Lisesi & 7 \\
\hline Kız İmam Hatip Lisesi & 17 \\
\hline Erkek İmam Hatip Lisesi & 6 \\
\hline Ortaokul & 6 \\
\hline Toplam & 57 \\
\hline
\end{tabular}

17 Araştırma sırasında oluşan kız erkek dağııımındaki dengesizlik, son odak görüşme olan Kız İmam Hatip Lisesinden görüşmeye katılacak olan kız öğrencilerin tüm sınıf arkadaşlarıyla birlikte görüşmeye gelmesinden ötürü yaşanmıştır. Odak grup görüşmesi gerçekleştirildiğinden veri kaybı yaşanmaması için her görüşme kayda eklenmiştir.

18 SES: Sosyo-ekonomik sınıf. Kişilerin ve ailelerinin eğitim, meslek, sosyal statüsü doğrultusunda ait olduğu sınıfın belirlenmesinde kullanılan değişkendir. Çalışmamızda kullanılan şekliyle AB grubu, eğitim ve sosyal düzeyi yüksek, C, eğitim ve sosyal düzeyi orta, DE ise eğitim ve sosyal düzeyi düşük grupları ifade etmektedir. 


\section{Bulgular ve Yorum}

\section{Kaybolan mesaj/veri kullanımı}

Sosyal medya uygulamalarının özelliklerinin benzerlikleri ve sürekli olarak güncelleme almalarından dolayı sosyal medyanın spesifik özellikleri üzerine araştırma yürütmenin oldukça zor olduğu öncelikle belirtilmelidir. Mesela Instagram ve Facebook uygulamaları öncesinde sadece fotoğraf, video arşivleme özellikleri bakımından kullanılırken, sonrasında entegre edilen "kaybolan mesaj/veri" özelliği bu uygulamaları daha kompleks bir yapıya dönüştürmüştür. Diğer bir yandan da bu özelliğin Instagram kullanan gençler tarafından oldukça hızlı benimsendiği görülmüştür. Fakat Facebook uygulaması için aynı çıkarımı yapmak mümkün değildir. Hatta gençler, Snapchat uygulamasını sadece direkt (özelden) mesajlaşma için kullanırken, Instagram hikâye özelliğini ise gündelik hayatlarında yoğun olarak kullanmaya başladıklarını dile getirmişlerdir. Instagram uygulamasında bu özelliğin benimsenmesi, bir anlamda da "arşivlenen içerikler" ile "kaybolan mesaj/ veri" içeriklerinin kullanım motivasyonlarındaki farklılıkları daha net olarak açığa çıkmasına olanak sağlamıştır. WhatsApp ve Facebook uygulamalarında ise "kaybolan mesaj/veri" özelliklerinin benimsenmediği hatta anlamsız bulunduğu ortaya çıkmıştır.

Sahadan elde edilen veriler doğrultusunda, kaybolan mesaj/veri kullanımında öne çıkan motivasyonlar aşağıdaki tablodaki gibidir;

Tablo 4. Kaybolan Mesaj/Veri Kullanım Motivasyonları

\begin{tabular}{|l|l|}
\hline Gizlilik: & $\begin{array}{l}\text { Kullanıcılara gizlilik içerisinde, } \\
\text { gözetlenmeden paylaşım imkânı } \\
\text { sağlaması. }\end{array}$ \\
\hline Anlık (Spontane) Fotoğraf: & $\begin{array}{l}\text { Arşivlenen içeriklerden farklı olarak, } \\
\text { kaybolan mesaj/veri anlık (spontane) } \\
\text { paylaşımlara imkan vermesi. }\end{array}$ \\
\hline Yakın Çevre: & $\begin{array}{l}\text { Sadece yakın çevre ile paylaşımda } \\
\text { bulunma imkânı. }\end{array}$ \\
\hline $\begin{array}{l}\text { Beğeni Endişesinden Kurtulmak } \\
\text { (Kaygısızlık): }\end{array}$ & $\begin{array}{l}\text { Beğeni kaygısının yüksek olduğu yaş } \\
\text { grubu içerisinde kaygısızca paylaşım } \\
\text { yapma imkânı sağlamaktadır. }\end{array}$ \\
\hline
\end{tabular}

\section{Gizliliğin Önemi}

Görüşmeciler, kaybolan mesaj/veri özelliğinin üçüncü kişilerin mesajları görmesini engellediğinden dolayı daha güvenli, özel bir mesajlaşma imkanına 
sahip olduklarını vurgulamışlardır. Böylelikle gençlerin "gizli kalmasını istedikleri içerikleri" paylaşma beklentileri kaybolan mesaj/veri özelliği ile karşılandığı görülmektedir. Bu gizlilik özelliğinin, kaybolan mesaj/veri için birincil kullanım motivasyonu olduğu söylenebilir. Bu özelliğin, görüşmeciler tarafından daha çoğunlukla Snapchat uygulamasının "direkt mesaj özelliği" ile ilişkilendirilmekte olduğu da belirtilmelidir.

Gençler, "kaybolan mesaj/veri"nin gönderildiği andan itibaren saniyeler içinde silinme özelliğini oldukça işlevsel bulduklarını açıkça belirtmektedirler. Yaptıkları paylaşımların içerikleri, arşivlenen ve tüm arkadaş listesi ile paylaşılan içeriklerden genellikle farklıdır ve hayatlarına dair daha özel anlarını ve detaylarını paylaşmak için "kaybolan mesaj/veri" kullanmaktadırlar. Bu kaybolma özelliği, sosyal medya kullanımlarında genel arkadaş listeleriyle paylaşmak zorunda kalmadan, gündelik hayatlarına dair kesitleri gizlilikle paylaşım yapabildikleri yeni bir mecra sağlamaktadır.

"Benim en çok kullandığım uygulama Snapchat kimseye atmadığım fotoğraflarımı oradan en yakın arkadaşlarımla paylaşabiliyorum. Mesela yakın arkadaşıma her fotoğrafımı gönderebilirim ama hikâyeme asla(burayı oldukça vurgulu bir şekilde söylüyor). "(17 yaş, kız, özel lise, A )

"Snapchat uygulamasını seviyorum çünkü yakın kız arkadaşlarıma (karşısındaki arkadaşını gösteriyor) istediğim gibi fotoğraf gönderebiliyorum. Mesela ben tişörtle bir fotoğraf koyamam ya da başım açık bir fotoğraf paylaşamam, telefondan göndersem şimdi orada kalabilir başkası görür. Ama Snapchat'te ev halimi atıyorum mesela, o kayboluyor sonra biliyorum. " (17 yaş, kız, Imam Hatip lisesi, D)

"Snapchat'in direkt mesaj olarak sadece 2-3 arkadaşıma atıyorum. Onda da attıklarım hep ev hali oluyor ya da aramızdaki özel daha önce yaşanmış bir konu hakkında oluyor. Mesela arkadaşlar arasında 'ifşalamak' diye bir şey var, işte kötü anlarını ifşalıyorsun Snapchat'ten çünkü sonra kayboluyor ya ondan bir şey olmuyor. " (16 yaş, kız, sağlık meslek lisesi, C1)

Gençler özellikle Facebook'u çok fazla yetişkin, akraba, ebeveyn kullandığı için artık kullanmadıklarını belirtmişlerdir. Bu nedenle Facebook'un kaybolan mesaj içeriği paylaşmalarını sağlayan "hikâyeler" kısmını da ebeveynlerinin veya akrabalarının görmelerini istemedikleri için kullanmayı tercih etmediklerini söylemektedirler. Gençlerin, ebeveynlerin yer almadığı platformları tercih etme istekleri, ergenliklerinde önemli bir yer tutan kimlik edinme sürecinin bir parçaSı, aileden kopma ve özerkleşme isteği olarak da yorumlanabilir (Uğur-Tanrı̈ver, 2008). Gençlerin yetişkinlerden ayrı olarak paylaşım yapabilecekleri bir uygulamaya duydukları intiyacın özellikle Snapchat ile karşılandığı görülmektedir. Bu uygulama gençler tarafından bir "kaçış yolu" olarak betimlenmiştir.

"Ben Facebook'umu kapattım. Yaşlar ilerliyor artık yaş grubu değişti. Ben akrabalarla, büyüklerle birlikte Facebook'ta olmaktan hoşlanmıyorum. Özel hayatımı onların tepkilerinden dolayı paylaşmak istemiyorum." (15 yaş, kız, Anadolu lisesi, C1) 


\section{Yakın Çevre ile Paylaşım}

Çalışmanın diğer önemli bulgusu, kaybolan mesaj/veri'lerin uzak ve tanınmayan bir çevre ile değil, yakın bir çevre ile paylaşıdığı üzerinedir. Ulaşılan bu bulgu, Vaterlaus ve arkadaşlarının (2016) kaybolan mesaj/veri özelliğinin yakın arkadaşlıklar, romantik ilişkiler gibi güçlü ilişkiler arasında kullanıldığı savını desteklemektedir. Bauman ve Lyon, "Akışkan Gözetim" (2013) eserlerinde bu kadar hızı değişen akışkan bir dünyada Facebook ve türevi sosyal medya mecralarının asıl görevlerinden birinin de çekirdek bir arkadaş grubunun devamlıı̆ııı sağlamak olduğunu vurgulamaktadır. Artık Facebook çekirdek arkadaş gruplarının devamlılığı için tercih edilmiyor olsa da, bu görevi kaybolan mesaj/veri özelliğinin (özellikle Snapchat ve Instagram uygulamalarının) devraldığını söylemek mümkündür.

"Bizim bir kı grubumuz var, bu kaybolan mesajları onlarla kullanıyorum. Her halimi arkadaşlarımla rahatça paylaşabilmek çok hoşuma gidiyor. Sonrasında o mesajlar nasılsa saklanmıyor da istediğim gibi gönderebiliyorum. " (15 yaş, kız, Güzel Sanatlar Lisesi, B)

"Snapchat'te ben herkese göndermiyorum mesela sadece görmesini istediklerime gönderiyorum, herkesin göreceği fotoğraflar ayrı, yakın arkadaşlarımın göreceği fotoğraflar ayrı. Ayrıca kuzenim teyzem filan da bazı sosyal medyaları kullanıyorlar, onların da her şeyimi görmesini istemiyorum. " (13 yaş, kız, ortaokul, C2)

Ayrıca yazılı olarak kurulan iletişim biçimlerinde yanlış anlaşılmalar mümkünken, fotoğraf ve videolarla kurulan iletişim biçimlerinde yanlış anlama ve anlaşıma ihtimalinin düşük olmasından ötürü gençler kaybolan mesaj/veri paylaşımlarını daha işlevsel bulduklarını belirtmişlerdir. Vaterlaus ve arkadaşlarının (2016) yaptığı çalışmasında da vurgulandığı gibi, kaybolan mesaj/veri özelliği gençlerin kendi iletişim kültürlerini oluşturmasına olanak sağlamıştır.

"Snapchat, WhatsApp'ın fotoğraflı hali gibi, mesela oradan hep haberleşiriz, her yaptığımı çok yakın 2 arkadaşım var onlarla paylaşııım mesela, ev halimi, ne yapıyorsam paylaşırım. Yazıyla iletişim kurduğumuzda, WhatsApp'tan filan ne yaptığını anlatmak uzun sürüyor ayrıca fotoğraf ile iletişim çok daha kolay hem yanlış anlaşılmalar da çok daha az oluyor. " (15 yaş, kız, Anadolu lisesi, C1).

\section{Anlık (Spontane) Fotoğraf Paylaşımı}

Çalışmanın saha verilerinden hareketle, kaybolan mesaj/veri kullanımının diğer motivasyonlarından birinin de "anı paylaşma" isteği olduğu görülmektedir. Bayer ve arkadaşlarının da belirttiği gibi (2015) anlık iletişim için kullanılan snap'ler küçük anları paylaşmaya yöneliktir. Görüşmeciler kaybolan mesajların paylaşılığı Snapchat, Instagram ve WhatsApp, Facebook uygulamalarında anlık (spontane) fotoğraf paylaşmanın kolaylığına dolayısıyla da anlarını paylaşmanın kolaylığına dikkat çekmektedir. Burada görüşmeciler uygulamaların teknik olarak kullanım kolaylıklarına da vurgu yapmaktadırlar. Facebook, Snapchat, WhatsApp ve Instagram uygulamalarının "hikâye" bölümüne tıklandığında kamera direkt olarak etkinleşmektedir ve kullanııılar kameraları ile çektikleri fotoğraf/videoları anında paylaşabildiklerini belirtmektedirler. 
Charteris ve Gregory (2014) çalışmasında da vurguladığı gibi kaybolan mesaj/veri içeriklerinin paylaşıldığı "hikâye" bölümleri gençler için daha fazla görme ve görülme olanağı sağlamaktadır. Görüşmeciler, kaybolan mesaj/veri özelliği ile gündelik hayatlarına dair anları sıklıkla ve görüşmecilerin tabiriyle "akıllarına estikleri" gibi paylaşmaktadırlar. Bu anı paylaşma hevesi, Foucault'ya referansla "öz-gözetim"19 kavramı çerçevesinde de düşünülebilir. Gözetleme, modernliğin önemli boyutlarından biri olarak değerlendirilmektedir (Giddens, 2004; Bauman ve Lyon, 2013). Sosyal paylaşım sitelerinde kişisel bir enformasyon değiş-tokuşu yapılmaktadır ve kişiler özel hayatlarını açıkça sergilemekten, kişisel bilgilerini eksiksiz olarak göndermekten mutludurlar (Bauman ve Lyon, 2013). Yapılan görüşmeler kapsamında da görüşmecilerin kaybolan mesaj/veri özelliğini "anı paylaşma" motivasyonu ile kullanıldığını ortaya çıkarmaktadır.

"Dışarıdayken kendi fotoğraflarımı koyuyorum evden pek fazla bir şey koymuyorum ben. Ben buradayım ben geldim diye beni takip edenlere göstermek amacıyla koyuyorum ben. Mesela eski sevgilin seni stalk'lıyorsa ${ }^{20}$ yanında birisi varsa kesinlikle koyarsın mesela. Geziyorum çok mutluyum diye mesaj verirsin ona. " (16 yaş, sağlık meslek lisesi, C2)

"Hikâyeye anlık fotoğraf koyarken yani ne bileyim düşünmezsin hiç üstüne. Ben mesela genellikle hafta sonları bir şeyler paylaşırım hikâye özelliğinde, çünkü dışarı çıkıyorum. Gittiğim sahilde bir kafe var mesela orayı paylaşırım, gezdiğim yerleri paylaşırım yani net bir şeyi yok hikâyede paylaştıklarımın. Evde de olabilir, o an canım isterse mesela, kamerayı açarım, hemen paylaşııım, fotoğraf paylaşmaktan daha kolay.' (17 yaş, Kız, Anadolu Lisesi, C1)

"Ben mesela ders çalışırken de koyabilirim, sevdiğim bir şeyin fotoğrafını çekince koyarım, bazen sadece şarkı sözü paylaşııım, kendimi geliştiriyorsam mesela kitap okuyorsam kendimi geliştiriyorum diye paylaşırım. Anlık yani aklıma o an ne eserse. " (15 yaş, kız, özel lise, A)

\section{Beğeni Endişesinden Kurtulmak (Kaygısızlık)}

Yapılan görüşmelerde beğenilme isteği ve beğenilme endişesinin gençler arasında oldukça önemli olduğu ortaya çıkmaktadır. Facebook ya da Instagram'da paylaşılan ve arşivlenen her içeriğin altında yorum ve beğen butonu bulunmaktadır. Özellikle Instagram uygulaması üzerinden kaybolan mesaj/veri kullanım motivasyonları sorgulandığında en güçlü motivasyonlarından birinin kaygısızca, çekinmeden, beğenilme algısı olmadan paylaşım yapmak olduğu gözlemlenmiştir. Bayer ve arkadaşlarının (2015) çalışmalarındaki bulgularla uyumlu olarak, kaybolan mesaj/veri içerikleri kullanıcılara bir rahatlama, kaygısızlık hissi sağlamakta, paylaşımları üzerine düşünme yükünden kurtarmaktadır.

"Mesela kalıcı olarak koyduğum fotoğrafların kesinlikli beğeni alacak fotoğraflar olması lazım. Beğeni almayacak fotoğrafları hikâyede paylaşır geçerim. Bir de hikâyede çok fazla insan görmüyor ama kalıcı fotoğrafları her zaman profilde hep görülme ihtimali var. " (16 yaş, Kız, Anadolu Lisesi, C1)

19 Makalenin orjinalinde 'self-surveillance' olarak kullanılmaktadır.

20 Sosyal medya platformlarında 'Stalk iz sürme, takip etme, dikizleme olarak değerlendirilir ve bu eylemi gerçekleştiren kişiye stalker, dikizleme eylemini de stalklamak olarak ifade etmek mümkündür' (Akmeşe ve Deniz, 2017). 
"Hikâyede fotoğraf paylaşırken herkes çok rahat. Ama profile bir fotoğraf koyulacağı zaman, sen oraya geç sen buraya geç, öyle poz ver böyle çek diyoruz. Ama hikâye özelliğinde, koyuyoruz istediğimiz gibi. Instagram'da da mesela Beşiktaş maçlarından en koyarım, onunla ilgili şeyler paylaşmak hoşuma gidiyor. " (17 yaş, erkek, özel lise, B)

"Ben kalıcı olacak fotoğrafların her detayına bakarım çok ederim ne paylaşıyorum diye ama hikâyede böyle bir dikkat etme durumum yok hemen ne yapıyorsam atarım. " (16 yaş, kız, sağlık meslek lisesi, C2)

"Benim profilim herkese açık, 1000'e yakın da takipçim var. Hatta arkadaşlarım benim için artık fenomen bile demeye başladılar... Eğer benim bir fotoğrafım beğenilmezse ben onu kaldırım, ya yeniden yüklerim ya da hiç yüklemem. " (16 yaş, kız, Güzel Sanatlar Lisesi, C1)

Kaygısızca fotoğraf paylaşabilme imkânı, paylaşımların içeriklerini de dönüştürmüştür. Direkt mesaj özelliğinin yanı sıra, özellikle arkadaş listelerinin görebildiği hikâye özelliğinde paylaşılan kaybolan mesaj/veri ile arşivlenen kısımda paylaşılan içeriklerin farklılıkları görüşmeciler tarafından sıklıkla vurgulanmıştır. Özellikle bu farkın kaybolan mesaj ile paylaşılan ve kalıcı olarak paylaşılan içeriklerde daha da derinleştiği gözlemlenmiştir.

"Arşivlenen fotoğraflarıma her şeyimi koymam. Oraya konulan fotoğraflar tablo gibi olmalı estetik durmalıdır, gösterişli durmalıdır. Hikâyede öyle anlık fotoğraflar paylaşıyorum daha çok. Kalıcı olarak paylaştığım fotoğraflarımda kendimi paylaşıyorum daha çok, hikâyede ise gittiğim yerleri." (16 yaşında, kız, Anadolu lisesi.)

Görüşmelerden elde edilen bulgulardan hareketle, direkt olarak belirli kişilere gönderilen içeriklerle ile toplu arkadaş listelerinin görebildiği hikâye özelliğinde paylaşılan içeriklerin farklılaştığı açıkça görülmektedir. Kaybolan veri kullanım biçimlerinde, fotoğrafların kalıcı mı yoksa anlık mı olarak mı paylaşılacağı fotoğrafın içeriğine göre belirlenmektedir. Bu bulgu, kaybolan mesaj içerikleri ile kalıcı olarak paylaşılan içeriklerin kullanım ve amaç farklıı̆ının olduğunu açıkça göstermektedir.

\section{Sonuç}

Kaybolan mesaj/veri, anlık(spontane) iletişim, geçicilik, beğeni endişesinden kurtulmak, (kaygısızlık) olarak kavramlarıyla ele alınan kaybolan mesaj/veri özelliği hakkında yapılan bu niteliksel çalışma, kaybolan mesaj/verinin, arşivlenen/ saklanan mesajlardan farkı kullanım pratiklerinin yarattığı açıkça görülmüştür. Kaybolan mesaj/verinin yeni bir iletişim dinamiği oluşturarak içeriği dönüştürmesi bu araştırmanın en önemli sonuçları arasındadır.

13-17 yaşları arasında, farklı okullarda okuyan (Özel Lise, Anadolu Lisesi, Kız/Erkek Imam Hatip Liseleri, Sağlık Meslek Liseleri, Güzel Sanatlar Lisesi) gençlerle yapılan araştırma sonucunda gizlilik isteği, yakın çevre ile iletişim kurma imkânı, anı paylaşma ve kaygısızca fotoğraf paylaşabilme gibi özellikler kaybolan mesaj/veri kullanım motivasyonları olarak karşımıza çıkmaktadır. Gençler, kullan- 
dıkları sosyal medya uygulamalarında yetişkinler aile, akraba ile birlikte bir arada olmaktan hoşlanmadıklarından her zaman onların tercih etmedikleri, uzak kaldıkları ya da bilmedikleri sosyal medya uygulamalarını tercih ettikleri gözlemlenmiştir.

Kaybolan mesaj/verinin gizli kalmasını, silinerek kimsenin görmemesini sağlayan özellik gençlerin ihtiyaç duyduğu özel alanı onlara eğlenceli bir şekilde sağlamıştır. Yakın çevre ile paylaşılan bu özel mesajlar, sosyal medyaların ağ mantığında olan kalabalık arkadaş listelerinin yanı sıra gençlere alternatif bir alan yaratmıştır.

Sosyal medya uygulamalarının doğası paylaşımdır ve bu paylaşım içerikleri zaman geçtikçe yoğunlaşmış ve hayatların her alanı paylaşııı olmuştur. Kaybolan mesaj/verinin, özellikle hikâye kısmında, içeriklerin kendiliğinden 24 saat sonra silinmesi, yıllardır arşivlenerek paylaşılan (yer bildirimleri, yenilen yemek fotoğrafları) daha gündelik fotoğrafların, (yapılan aktiviteler vb.) uçup gitmesine olanak sağlamıştır. Ayrıca sosyal medyada eklenilen fotoğrafların yüksek beğenilme kaygı taşıması, kaybolan mesaj özelliğinin iletişimde daha yoğun ve kaygısızca kullanılmasına olanak vermiştir.

Kaybolan mesaj özelliği bir sosyal medya uygulaması olsa da, gençlerle yapılan kullanım motivasyonları çalışmasında aslında gençlik kültürü ve bu kültürün intiyaçları hakkında önemli ipuçları vermektedir. Sosyal medya uygulamaları her gün sürekli güncellenen bir yapıya sahiptir ve yeni ihtiyaçlar ortaya çıktıkça, yeni uygulamalar da gündelik hayata girecektir.

\section{Kaynakça}

Anderson, K. E. (2015). Getting Acquainted With Social Networks And Apps: Snapchat And The Rise Of Ephemeral Communication. Library Hi Tech News, 32(10), 610. https://doi.org/10.1108/LHTN-11-2015-0076.

Akmeşe, Z., \& Deniz, K. (2017) Stalk, Benliğin İzini Sürmek. Ege Üniversitesi İletişim Fakültesi Yeni Düşünceler Hakemli E-Dergisi, (8), 23-32.

Ayhan, B., \& Çavuş, S. (2014). İzleyici Araştırmalarında Değişim: Kullanımlar ve Doyumlardan Bağımlılığa. Selçuk Üniversitesi Illetişim Fakültesi Akademik Dergisi, 8(2), 3260.

Ayvaz, T. (2017). Internet Ve Sosyal Medya Kullanıcı İstatistikleri 2017. Erişim 27 Mayıs 2018, http://www. dijitalajanslar.com/internet-ve-sosyal-medya-kullanici-istatistikleri-2017/.

Bağcı, C. (2017). Sosyal Medya Pazarlama İstatistikleri - 2017 I Blog AdresGezgini. Erişim 10 Mayıs 2017, https://blog.adresgezgini.com/sosyal-medya-pazarlama-istatistikleri-2017/.

Bayer, J. B., Ellison, N. B., Schoenebeck, S. Y., \& Falk, E. B. (2015). Sharing 
the small moments: ephemeral social interaction on Snapchat. Information, Communication \& Society, 4462(January), 1-22. https://doi.org/10.1080/13691 18X.2015.1084349.

Berelson, B. (1949). What 'missing the newspaper' means? In P. F. Lazarsfeld \& F. N. Stanton (Ed.), Communications research 1949- 1948 (pp. 111-129). New York: Harper.

Boyd, D. M., Ellison, N. B. (2008). Social Network Sites: Definition, History, and Scholarship, Journal of Computer-Mediated Communication (13), 210-230.

Bumgarner, B. A. (2007). You Have Been Poked: Exploring the Uses and Gratifications of Facebook Among Emerging Adults. First Monday, 12(11).

Charteris, J., Gregory, S., \& Masters, Y. (2016). 'Snapchat', Youth Subjectivities And Sexuality: Disappearing Media And The Discourse Of Youth Innocence. Gender and Education, 253(June), 1-17. https://doi.org/10.1080/09540253.2016 .1188198 .

Garde-Hansen, J., Hoskins, A., \& Anna, R. (2009). Save as... Digital Memories. (J. Garde Hansen, A. Hoskins, \& R. Anna, Eds.). Palgrave Macmillan. Göncü, S. (2018). Kullanımlar ve Doyumlar Yaklaşımı Çerçevesinde Y Kuşağının WhatsApp Kullanımı Üzerine Bir İnceleme. TRT Akademi, 3 (6), 590-612.

Charteris, J., Gregory, S., Y. M. (2014). Snapchat 'selfies': The case of disappearing data.

Critical Perspectives on Educational Tehnology, (1995), 1-5. https://doi. org/10.1177/0959354305053217.READS.

Ellison, N., Steinfield, C., \& Lampe, C. (2006). Spatially bounded online social networks and social capital. International Communication Association, 36(1-37).

Kaplan, A. M., \& Haenlein, M. (2010). Users of the world, unite! The challenges and opportunities of Social Media. Business Horizons, 53(1), 59-68. https://doi. org/10.1016/j.bushor.2009.09.003.

Kara, T. (2016). Gençler Neden Snapchat Kullanıyor Kullanımlar Ve Doyumlar YakIaşımı Üzerinden Bir Araştırma. Intermedia International E-Journall, 33(355). https://doi.org/10.21645/intermedia.2017.14.

Köseoğlu, Ö. (2012). Sosyal Ağ Sitesi Kullanıcılarının Motivasyonları:Facebook Üzerine Bir Araştırma. Selçuk Üniversitesi İletişim Fakültesi Akademik Dergisi, $7(2), 58-81$.

Ong, W. J. (2002). Orality and literacy. London: Routledge.

Özdemir, M. (2010). Nitel veri analizi: Sosyal bilimlerde yöntembilim sorunsaI üzerine bir çalışma. Eskişehir Osmangazi Üniversitesi Sosyal Bilimler Dergisi, 11(1).

Özkul, D., \& Humphreys, L. (2015). Record and remember: Memory and mea- 
ning-making practices through mobile media. Mobile Media \& Communication, 3(3), 351-365. https://doi.org/10.1177/2050157914565846.

Papacharissi, Z. (2008). Uses and gratifications. An Integrated Approach to Communication Theory and Research.

Papacharissi, Z. a. (2010). A Networked Self. Social Networks. https://doi. org/10.4324/9780203876527.

Park, I. (2004). Internet usage of Korean and American students: A uses and gratifications approach. http://aquila.usm.edu/theses_dissertations/3670/.

Park, N., Kee, K. F., Valenzuela, S. (2009) Being Immersed in Social Networking Environment: Facebook Groups, Uses and Gratifications, and Social Outcomes. CyberPsychology \& Behavior 12.6: 729-733.

Piwek, L., \& Joinson, A. (2016). 'What do they snapchat about?' Patterns of use in time limited instant messaging service. Computers in Human Behavior, 54, 358-367. https://doi.org/10.1016/j.chb.2015.08.026.

Quan-Haase, A., \& Young, A. L. (2010). Uses and gratifications of social media: A comparison of Facebook and instant messaging. Bulletin of Science, Technology \& Society, 30, 350-361. https://doi.org/10.1177/0270467610380009.

Ramirez, A. K., \& Broneck, K. (2009). 'IM me': Instant Messaging As Relational Maintenance And Everyday Communication. Journal of Social and Personal Relationships, 26(2-3), 291 314. https://doi.org/10.1177/0265407509106719.

Rubin, A. M. (1983). Television uses and gratifications: The interactions of viewing patterns and motivations. Journal of Broadcasting, 27(1), 37-51. https://doi. org/10.1080/08838158309386471.

Rubin, A. M. (2002). The uses-and-gratifications perspectives of media effects. In J. Bryant \& D. Zillmann (Eds.), Media effects. Advances in theory and research (Second Edi, pp. 525, 549). Lawrence Erlbaum Associates.

Ruggiero, T. E. (2009). Mass communication and society uses and gratifications theory in the 21st Century. Mass Communication and Society, 3(1), 3-37. https:// doi.org/10.1207/S15327825MCS0301.

Sashittal, H. C., DeMar, M., \& Jassawalla, A. R. (2016). Building acquaintance brands via Snapchat for the college student market. Business Horizons, 59(2). https://doi.org/10.1016/j.bushor.2015.11.004.

Schramm, W., Lyle, J., \& Parker, E. (1961). Television in the lives of our children. Stanford University Press, Stanford, Calif.

Stanton, F., \& Lazarsfeld, P. (1944). Radio Research: 1942-1943. New York: Duell, Sloan\&Pearce.

Taprial, V., \& Priya, K. (2012). Understanding Social Media. Bookboon (Vol. 1). https://doi.org/10.1017/CBO9781107415324.004. 
Türkiye, Instagram Hikâyeler özelliğini en çok kullanan 4'üncü ülke - Teknoloji Haberleri. (2017). Erişim 2 Şubat 2018, http://www.hurriyet.com.tr/turkiye-instagram-hikayeler-ozelligini-en-cok-kullanan-4uncu-ulke-40539998.

Utz, S., Muscanell, N., \& Khalid, C. (2015). Snapchat Elicits More Jealousy Than Facebook: A Comparison Of Snapchat And Facebook Use. Cyberpsychology, Behavior, and Social

Networking, 18(3), 141-146. https://doi.org/10.1089/cyber.2014.0479.

Van Dijck, J. (2007). Mediated Memories in the Digital Age. London:Stanford University Press.

Vaterlaus, J. M., Barnett, K., Roche, C., \& Young, J. A. (2016). 'Snapchat Is More Personal': An Exploratory Study On Snapchat Behaviors And Young Adult Interpersonal Relationships. Computers in Human Behavior, 62, 594-601. https://doi. org/10.1016/j.chb.2016.04.029.

Webster, J. G., \& Shu-Fang, L. (2002). The Internet Audience: Web Use as Mass Behavior. Journal of Broadcasting \& Electronic Media, 46(1), 1. https://doi. org/10.1207/s15506878jobem4601_1.

Zhao, X., \& Lindley, S. (2014). Curation Through Use : Understanding The Personal Value Of Social Media. Proceedings of CHI, pp. 2431-2440. ACM.

Yayla, H . (2018). Kullanımlar ve Doyumlar Bağlamında Dokuz Eylül Üniversitesi Güzel Sanatlar Fakültesi Öğrencilerinin Sosyal Medya Kullanımı: Instagram Örneği. Selçuk Üniversitesi İletişim Fakültesi Akademik Dergisi, 11 (1), 40-65. DOI:10.18094/josc.346756.

Yıldıım, Ş., Özdemir, M., \& Alparslan, E. (2018). Kullanımlar ve doyumlar kuramı çerçevesinde bir sosyal paylaşım ağı incelemesi: Facebook örneği. Intermedia International eJournal ISSN: 2149-3669, 5(8), 42-65.

Yıldırım, A., \& Şimşek, H. (2008). Nitel Araştırma Yöntemleri.(7. Baskı). Ankara: Seçkin Yayıncılık.

Xu, B., Chang, P., Welker, C. L., Bazarova, N. N., \& Cosley, D. (2016). Automatic Archiving versus Default Deletion: What Snapchat Tells Us About Ephemerality in Design. In Proceedings of the 19th ACM Conference on Computer-Supported Cooperative Work \& Social Computing - CSCW '16. https://doi. org/10.1145/2818048.2819948. 